\title{
FEMINICÍDIO: CRIME HEDIONDO CONTRA A MULHER
}

\author{
https://dx.doi.org/10.48097/2674-8673.2021n5p11
}

\author{
Soraya Manoela Alves da Silva ${ }^{1}$ \\ Carlos Cavalcanti ${ }^{2}$
}

\section{RESUMO}

Este artigo traz um estudo sobre a questão da violência contra a mulher, com destaque para a discussão do feminicídio, suas causas e consequências. Através da reconstrução de nossas raízes históricas e culturais, é mostrado que a violência contra a mulher é um fato não apenas corriqueiro, mas aceito e justificado por toda uma ideologia machista e sexista de dominação. A lei do feminicídio, assim como a lei Maria da Penha, aparecem como respostas dadas pelos movimentos em defesa da mulher para este grave problema. A definição de crime hediondo e homicídio qualificado para o assassinato de mulheres representa um marco em nossa legislação penal, fruto do reconhecimento de que as questões de gênero são importantes e devem ser debatidas por todos.

Palavras-chave: Feminicídio. Lei Maria da Penha. Código Penal. Gênero.

Data de submissão: 25/02/2021

Data de aprovação: $24 / 03 / 2021$

\begin{abstract}
This article brings a study on the issue of violence against women, with emphasis on the discussion of feminicide, its causes and consequences. Through the reconstruction of our historical and cultural roots, it is shown that violence against women is not only a common fact, but accepted and justified by a sexist ideology of domination. The feminicide law, as well as the Maria da Penha law, appear as responses given by the movements in defense of women to this serious problem. The definition of heinous crime and qualified homicide for the murder of women represents a milestone in our penal legislation, the result of the recognition that gender issues are important and must be debated by everyone.
\end{abstract}

Keywords: Feminicide. Maria da Penha Law. Penal Code. Gender.

\section{INTRODUÇÃO}

A sociedade brasileira ainda é muito machista e preconceituosa, principalmente quando se trata de defender os direitos das mulheres e protegê-las do assédio e da violência

\footnotetext{
${ }^{1}$ Discente do Curso de Bacharelado em Direito da Faculdade Metropolitana da Grande Recife. E-mail: melindaluisa@outlook.com

2 Orientador / Docente do Curso de Bacharelado em Direito da Faculdade Metropolitana da Grande Recife. E-mail: carloscavalcanti@metropolitana.edu.br
} 
dos homens, dos quais muitos ainda se acham no direito de fazer o que quiserem com suas companheiras, desde a traição até a violência física.

Este cenário vem mudando ao longo dos anos, num movimento em que a mulher vem ganhando cada vez mais consciência do seu papel como protagonista da sociedade, e a própria sociedade vem reconhecendo sua dignidade, ampliando seus direitos, coibindo e punindo todas as formas de violência contra a mulher.

Muitas leis têm surgido para proteger as mulheres da violência, principalmente a doméstica, a mais comum dentre elas. A Constituição foi um passo importante, pois trouxe, ainda que de maneira indireta, a discussão a respeito da valorização da mulher e do combate à violência por ela sofrida.

Além da Constituição, é preciso destacar, de forma ainda mais forte, a importância da Lei 11.340/2006, conhecida como Lei Maria da Penha, que se tornou um marco na luta e no combate à violência doméstica. Esta lei representou um enorme avanço no combate à violência contra a mulher. Juntamente com a lei, foi se formando uma estrutura protetiva que visava garantir ainda mais a proteção da mulher contra seus agressores.

Daí surgiram as delegacias especializadas no enfrentamento à violência doméstica, dando mais segurança às vítimas. Porém, a violência contra a mulher ainda persiste e ainda convive com uma mentalidade arcaica, em que os homens se acham no direito de agredir suas companheiras.

Para fortalecer ainda mais o combate a este tipo de prática, foi instituída a lei 13.104, de 09 de março de 2015, e que ficou conhecida como a lei do feminicídio, a qual veio para aumentar o rigor das penalidades e dar maior gravidade aos crimes cometidos com base no gênero, envolvendo quase sempre o homem e sua companheira. A partir desta lei, o feminicídio passou a ser previsto como circunstância qualificadora de homicídio, além de ser incluído no rol dos crimes hediondos.

A pergunta que norteia este trabalho é a seguinte: ao ser tratado como crime hediondo, o feminicídio contribui para diminuir a violência contra a mulher? O objetivo desta pesquisa é mostrar de que forma a lei do feminicídio contribui para ampliar a discussão a respeito da violência contra a mulher, combatendo as várias formas pelas quais esta se manifesta.

O debate a respeito da condição da mulher em nossa sociedade vem crescendo cada vez mais. A presente pesquisa é de caráter qualitativo, baseada no estudo da doutrina jurídica, no estudo a respeito da violência contra a mulher e na análise das leis e da jurisprudência.

Para melhor aprofundar o tema, o artigo foi dividido em três partes. Na primeira, é apresentada uma discussão a respeito da violência de gênero, sobretudo no que diz respeito à 
mulher. Na segunda parte, introduzimos a legislação a respeito da mulher, com destaque para a Lei Maria da Penha. E na parte final é apresentada a lei do feminicídio, seus aspectos principais, bem como os avanços que ela se propôs a fazer no combate à violência contra a mulher.

\title{
A VIOLÊNCIA DE GÊNERO
}

É necessário deixar claro que se trata de um ato de violência praticado, sobretudo, por aqueles que se consideram superiores às mulheres e que veem sua condição de mando e superioridade serem ameaçados pela ascensão delas, uma vez que as mesmas estão cada vez mais ocupando espaços na sociedade que antes eram ocupados pelos homens.

Ao definir a violência Saffioti (2004, p. 17) diz que ela é uma "ruptura de qualquer forma de integridade da vítima: integridade física, integridade psíquica, integridade sexual, integridade moral". Podemos notar que a referida autora traz um conceito amplo de violência, não se limitando apenas ao elemento físico, ao corpo, mas abarcando todos os outros aspectos que compõem o ser humano e que, por isso mesmo, entram na lista de fatores desencadeadores da violência.

Em seu artigo sobre a violência contra a mulher, Lays Conceição Franco (2014) diz que "ao abordar a violência contra a mulher, vincula-se o termo violência de gênero, enquanto sinônimo e expressão no sentido de produzir efeitos, ao que tange a violência contra mulheres perpetrada por homens, na condição de dominador/explorador”.

Neste sentido, a autora afirma que

\begin{abstract}
os avanços que as mulheres conquistaram, em termos sociais e culturais, nas mais diversas categorias histórico-políticas, configurados em maior nível educacional, possibilidades profissionais, consequentemente, certa autonomia econômica, trouxe consigo maior inconformismo, visto que os homens passaram a viver em um espaço de disputa, deixando, mesmo que gradualmente, de serem sempre vistos como sexo superior, cujas atitudes eram inquestionáveis e deveriam ser respeitadas. (LAYS, 2014, p. 54).
\end{abstract}

É inegável que as mulheres alcançaram outro patamar em nossa sociedade. Elas passaram muito tempo vivendo à sombra dos homens, como apêndice do lar, atuando apenas como dona de casa, esposa, mãe e cuidadora dos filhos, sem perspectivas que não a de acompanhar e ajudar no crescimento material e profissional do homem, o que sempre a prejudicou, colocando-a numa situação de inferioridade e, mais ainda, de exploração de sua condição feminina. 


\title{
Sociedade e Machismo
}

O feminicídio se insere dentro de um contexto representado por uma sociedade patriarcal, patrimonialista e machista. Considerar estes elementos nos ajuda a entender melhor os aspectos conceituais do feminicídio, bem como sua caracterização na literatura e legislação jurídica.

Em relação à nossa formação histórica, marcada por um processo de colonização europeu que se utilizou largamente da mão de obra escrava indígena e negra, bem como por um regime econômico de monocultura da cana e centrado na família do patriarca, os traços de autoritarismo por parte do homem são muito fortes.

Os casamentos por contrato, advindos de interesses econômicos eram muito comuns no início de nossa formação. Através do oferecimento de um dote, o pai presenteava sua filha com o varão abastado que comprava seu amor, afeição, cuidado, afeto. Por ser protetor, o homem devia cumprir o seu dever de corrigir sua esposa, aplicando inclusive castigos físicos.

Afinal de contas, a mulher lhe pertence, é um sujeito frágil, frívolo. O homem é a própria representação da força, coragem, decisão. Ele é o desbravador; a mulher, a terra a ser desbravada. É justamente destas construções que podemos retirar a figura do masculino como o sujeito da sexualidade. Em seu trabalho sobre a relação entre machismo e violência, Maria Cecília de Souza Minayo diz que:

\begin{abstract}
A concepção do masculino como sujeito da sexualidade e o feminino como seu objeto é um valor de longa duração da cultura ocidental. Na visão arraigada no patriarcalismo, o masculino é ritualizado como o lugar da ação, da decisão, da chefia, da rede de relações familiares e da paternidade como sinônimo de provimento material: é o "impensado" e o "naturalizado" dos valores tradicionais de gênero. Da mesma forma e em consequência, o masculino é investido significativamente com a posição social (naturalizada) de agente do poder da violência, havendo, historicamente, uma relação direta entre as concepções vigentes de masculinidade e o exercício do domínio de pessoas, das guerras e das conquistas. $\mathrm{O}$ vocabulário militarista erudito e popular está recheado de expressões machistas, não havendo como separar um de outro. (MINAYO, 2005, p. 77).
\end{abstract}

Segundo a autora, há uma relação direta entre masculinidade e violência. O másculo é aquele sujeito capaz de demonstrar sua força sempre que necessário. Aliás, este é o fundamento de sua existência, sua razão de ser. Ao homem é negada toda e qualquer demonstração de fraqueza, dor, medo. Isso pertence à condição feminina, marcada pela fragilidade, doçura e aceitação do domínio masculino. Isto se expressa também no mundo da criminalidade e dos atos violentos, como nos diz Minayo:

No mundo da criminalidade, a ideia fundante de macho violento se centra na mesma crença arraigada do masculino como o espaço da iniciativa, do poder e da imposição da vontade, fazendo a associação de dois planos, o da sexualidade e o da sociabilidade. A moral do macho violento é a da virilidade que se apodera do corpo, dos desejos, dos projetos, dos negócios e da vida do outro. (MINAYO, 2005, p.78). 
Quando traçamos um paralelo destes comportamentos em relação à forma como o homem percebe sua relação com a mulher, observamos então estes mesmos traços e atitudes, que denotam uma percepção de si mesmo como sujeito de direito sobre o corpo e a vida da mulher. Neste sentido, a violência e a sua autojustificação se complementam. Se a mulher foi morta ou agredida, certamente o mereceu, pois desrespeitou o elemento masculino, não se submeteu ao seu mando e controle. E isto serve, perigosamente, de pretexto para que o homem se veja no direito de atentar contra a integridade física de sua companheira, vizinha, estranha, etc. Em todas estas situações podemos perceber a presença do feminicídio.

\section{Feminicídio: aspectos conceituais}

Para caracterizar o feminicídio é necessário fazer a sua relação com a violência de gênero, pois ele é a sua expressão mais visível. Não vamos nos deter aqui no conceito jurídico, pois faremos isto no próximo tópico, quando analisarmos as definições trazidas pelo ordenamento jurídico específico sobre tal questão. O que importa neste momento é compreender suas razões e qualificações sociais a fim de que se torne mais claro para nós as razões pelas quais nossa legislação enfrentou este problema.

O interessante estudo sobre o feminicídio e sua invisibilidade, organizado pelas pesquisadoras Débora Prado e Marisa Sanematsu, e patrocinado pelo Instituto Patrícia Galvão, trata este tema à luz das questões culturais e sociais ligadas ao gênero. Daí se afirma que:

Para entender o que é o feminicídio é necessário compreender o que é a violência de gênero, já que o crime de feminicídio é a expressão extrema, final e fatal das diversas violências que atingem as mulheres em sociedades marcadas pela desigualdade de poder entre os gêneros masculino e feminino e por construções históricas, culturais, econômicas, políticas e sociais discriminatórias. (PRADO; SANEMATSU, 2017, p.16).

Portanto, o feminicídio está relacionado à violência sofrida pelas mulheres simplesmente por causa da condição de pertencerem ao gênero feminino. Isto ocorre por causa de construções históricas que colocam a mulher numa situação dada, mostrando que seu lugar na sociedade já está definido e que a não aceitação desta condição implica uma rebelião contra tudo o que já foi estabelecido pela própria sociedade. $\mathrm{Na}$ verdade, boa parte da educação das filhas durante muito tempo esteve voltado para o aprendizado dos afazeres domésticos e para a preparação da mesma para as tarefas que deveriam ser executadas no matrimônio. Para muitas famílias, o mais importante era dar a suas filhas um bom casamento, arranjar um bom esposo, ou seja, um homem capaz de sustentá-la financeiramente, 
proporcionando o conforto e a segurança que ela encontrava no aconchego do lar, sobre a presidência e autoridade do pai.

Saffioti (2004) vai relacionar a questão do gênero dentro da discussão sobre o patriarcado, pois para ela não dá para descolar uma coisa da outra, pois o gênero não é um conceito neutro, mas uma categoria que pode ser visualizada e compreendida historicamente a partir de relações determinadas de poder que estão presentes em todas as relações sociais.

Partindo destas distinções, Saffioti (2004, p. 136) diz que "tratar esta realidade exclusivamente em termos de gênero distrai a atenção do poder do patriarca, em especial como homem/marido, 'neutralizando' a exploração-dominação masculina”. É justamente por não ser um conceito neutro que o gênero, nas palavras de Saffioti (2004, p. 136) "carrega uma dose apreciável de ideologia”, ou seja, ele está muitas vezes marcado por esta expressão do patriarcado que tenta neutralizar o termo, apresentando-o apenas como mera diferença entre os sexos. Diante desta constatação a respeito da relação conceitual entre gênero e patriarcado, Saffioti diz que:

Assim, se gênero é um conceito útil, rico e vasto, sua ambiguidade deveria ser entendida como uma ferramenta para maquiar exatamente aquilo que interessa ao feminismo: o patriarcado, como um fato inegável para o qual não cabem as imensas críticas que surgiram. (SAFFIOTI, 2004, p. 136).

Estamos, pois, diante de uma situação de desigualdade. E não nos referimos ao aspecto físico, ao elemento de fragilidade supostamente presente na condição física da mulher, mas em outros aspectos que tornam as relações entre gêneros desiguais e opressivas para as mulheres. Como dizem Prado e Sanematsu:

\footnotetext{
Essas desigualdades e discriminações manifestam-se de diversas formas, que vão do acesso desigual a oportunidades e direitos até violências mais graves. É esse círculo que alimenta a perpetuação dos casos de assassinatos de mulheres por parentes, parceiros ou ex que, motivados por um sentimento de posse, não aceitam o término do relacionamento ou a autonomia da mulher. Ou ainda as mortes associadas a crimes sexuais e aqueles em que a crueldade revela o ódio ao feminino, entre outros casos. (PRADO; SANEMATSU, 2017, p. 19).
}

Como ressaltado pelas autoras, as oportunidades são desiguais. A própria remuneração das mulheres no mercado de trabalho é inferior aos homens, levando a uma situação de contrastes múltiplos, onde se revela uma violência social. Concomitante a isto temos a violência física e a violência simbólica, que se alimentam mutuamente e que são perpetradas por seus companheiros, que se acham donos de suas parceiras, praticando inclusive crimes de ordem sexual contra as mesmas.

Diante de todo este cenário social, e por causa da resistência das mulheres e de vários grupos na sociedade, a questão do feminicídio passou a ser tipificada em nossa legislação, 
contribuindo desta forma para a punição daqueles que se utilizam de argumentos naturalistas e machistas para agredirem suas companheiras.

\section{A TIPIFICAÇÃO DA VIOLÊNCIA DE GÊNERO NA LEGISLAÇÃO}

Ao longo da história a violência contra a mulher foi, não apenas tolerada, como justificada pela sociedade e tudo isto com base em argumentos filosóficos, religiosos, políticos, sociológicos, etc. Como não poderia deixar de ser, os diversos códigos legislativos corroboraram esta violência, adequando suas normas a esta situação de opressão social por parte de uma sociedade machista contra a mulher.

O caminho foi longo e árduo até se chegar às leis que pudessem amparar e condenar tais atos violentos praticados principalmente pelos companheiros e pessoas próximas das mulheres. As lutas pelo reconhecimento da dignidade da mulher na sociedade se estenderam desde o campo dos direitos políticos, permitindo o voto, a participação nas assembleias, a possibilidade de concorrer a cargos eletivos, dentre outros.

Porém, apesar de todos estes avanços, as práticas violentas continuaram a ser exercidas sobre a mulher, levando as mesmas a lutar incessantemente pelo estabelecimento de leis que garantissem sua proteção contra tais arbitrariedades e a punição daqueles que praticassem atos de violência, baseados numa errônea ideia de superioridade do masculino sobre a condição feminina.

\section{Evolução histórica do crime contra a mulher}

A posição da mulher ao longo da história, no Ocidente, foi a de cumprir um papel subalterno em relação ao homem, tendo suas funções restritas à reprodução e cuidado dos filhos, mantendo-se fiel ao marido durante toda a sua vida. Isto não ocorria de forma uniforme em todos os períodos e civilizações, mas constitui uma regra básica no tratamento e na visão que se tinha do papel da mulher na sociedade.

As ideias referentes à fidelidade, traição, adultério, estavam relacionadas geralmente aos atos praticados pela mulher e que geravam uma reprovação social de grande alcance. Em seu trabalho sobre a violência contra a mulher, Rosilene Almeida Santiago e Maria Thereza Ávila Dantas Coelho (2007) fazem uma breve contextualização histórica da questão da violência contra a mulher. A famosa lei de Talião (olho por olho, dente por dente) era muito rígida em relação às questões morais. Na Mesopotâmia, o casamento era considerado um ato de compra da mulher. Ela não podia rejeitar o marido, sequer falar mal dele publicamente, sob 
pena de ser atirada ao rio, com os pés e mãos amarradas. Outros casos históricos são retratados por Coelho e Santiago:

No Direito Romano, não cabia ao Estado a punição do delito da mulher, ou seja, as infratoras não eram punidas com pena pública, ficando esta tarefa sob a responsabilidade do homem. Durante a Idade Média, a discriminação contra a mulher foi a mais cruel. Para cada dez bruxas queimadas na fogueira da Inquisição, apenas um era bruxo. (COELHO; SANTIAGO, 2007, p. 112).

Podemos perceber que no século XIX, marcado pela consolidação do capitalismo como sistema econômico, ou seja, com a derrubada total do sistema feudal medieval, a mulher ainda era tratada de forma subalterna, sendo que o homem era visto como um ser dotado de grandes capacidades.

Devido a nossa formação histórica estar relacionada ao patriarcalismo, a situação da mulher foi bastante precária em relação à proteção da legislação em casos de agressão por parte do homem. No Período Imperial o adultério passou a ser punido. No caso, a mulher adúltera "cumpria pena de um a três anos, com trabalhos forçados" (Coelho e Santiago, 2007). $\mathrm{O}$ ato adulterino cometido pela esposa era considerado uma afronta à dignidade do homem, algo que prejudicava a sua imagem pública.

No começo do século XX, no Brasil, ainda era muito comum ler notícias nos jornais que falavam de assassinatos de mulheres por seus companheiros, tudo isto movido por questões passionais. Coelho e Santiago (2007) lembram o artigo 27 do código penal de 1890, em que cita que a pena do acusado por crimes passionais "pode ser absolvida ou amenizada, com o argumento de que os sentidos e a inteligência do réu se tornam privados durante o ato criminoso, sob os impulsos da duradoura paixão ou, mesmo, da súbita emoção".

O código penal de 1940, segundo Coelho e Santiago:

Eliminou a licitude relativa à "perturbação dos sentidos e da inteligência", que deixava impunes os assassinos chamados de passionais, adotando a categoria "homicídio privilegiado", pela qual o criminoso, mesmo tendo uma pena menor do que o homicídio simples (6 anos), não fica mais impune. (COELHO; SANTIAGO, 2007, p. 122).

Entretanto, a alegação de homicídio privilegiado continuou sendo largamente usado para justificar a ideia de crime passional, reportando tudo isto à questão da legítima defesa da honra e da dignidade. Foi necessário esperar a Lei Maria da Penha e a lei conta o feminicídio para que esta questão fosse tratada sob a ótica do respeito à dignidade da mulher, de forma a não buscar as mais diversas justificativas para isentar o homem (marido, companheiro) do ato criminoso em relação à mulher. Neste novo cenário, a vítima não mais passa a ser a culpada pelo seu infortúnio, uma vez que nada pode justificar um ato de tal natureza, que tire a vida de outra pessoa. 


\section{A lei Maria da Penha}

Um dos primeiros dispositivos legais a tratar da questão da violência contra a mulher foi a Lei 11.340/06, conhecida como Lei Maria da Penha, um marco da história da proteção legal às mulheres em nosso país. Sabemos que a constituição de 1988 consagrou o princípio da igualdade de todos perante a lei, incluindo nesta lista de itens, a questão da igualdade de gêneros, conforme está escrito no seu artigo $5^{\circ}$, parágrafo $1^{\circ}$, o qual diz que "homens e mulheres são iguais em direitos e obrigações, nos termos desta Constituição". Não resta dúvida sobre o que a carta magna propõe em termos de isonomia no tratamento entre os sexos.

No artigo 226, parágrafo $8^{\circ}$, o texto constitucional diz que “o Estado assegurará a assistência à família na pessoa de cada um dos que a integram, criando mecanismos para coibir a violência no âmbito de suas relações". Porém, houve a necessidade de criar outro dispositivo legal, na forma de lei ordinária, para regulamentar, dar finalidade prática ao dispositivo constitucional. A Lei Maria da Penha (11.340/06), que serve a este propósito, afirma em seu parágrafo primeiro:

Art. $1^{\circ}$ Esta Lei cria mecanismos para coibir e prevenir a violência doméstica e familiar contra a mulher, nos termos do $\S 8^{\circ}$ do art. 226 da Constituição Federal, da Convenção sobre a Eliminação de Todas as Formas de Violência contra a Mulher, da Convenção Interamericana para Prevenir, Punir e Erradicar a Violência contra a Mulher e de outros tratados internacionais ratificados pela República Federativa do Brasil; dispõe sobre a criação dos Juizados de Violência Doméstica e Familiar contra a Mulher; e estabelece medidas de assistência e proteção às mulheres em situação de violência doméstica e familiar.

O principal foco da lei foi prevenir a violência doméstica, pois é sabido que boa parte dos casos de agressão contra a mulher ocorre no ambiente familiar, perpetrada quase sempre pelos seus próprios companheiros. É por isto que a lei enfatiza esta situação específica, pois ela faz parte do cotidiano de muitas mulheres. Ela também estabelece medidas protetivas para que os atos de violência não cheguem a ser consumados, propondo, inclusive, a criação dos juizados e delegacias especiais para a proteção e amparo da mulher vítima da violência doméstica. Os artigos seguintes que compõem o preâmbulo da lei são igualmente importantes, pois ilustram a relação da lei com o que está posto em nossa carta magna:

Art. $2^{\circ}$ Toda mulher, independentemente de classe, raça, etnia, orientação sexual, renda, cultura, nível educacional, idade e religião, goza dos direitos fundamentais inerentes à pessoa humana, sendo-lhe asseguradas as oportunidades e facilidades para viver sem violência, preservar sua saúde física e mental e seu aperfeiçoamento moral, intelectual e social.

Art. $3^{\circ}$ Serão asseguradas às mulheres as condições para o exercício efetivo dos direitos à vida, à segurança, à saúde, à alimentação, à educação, à cultura, à moradia, ao acesso à justiça, ao esporte, ao lazer, ao trabalho, à cidadania, à liberdade, à dignidade, ao respeito e à convivência familiar e comunitária. 
De fato, isto representa um grande salto qualitativo no estabelecimento das condições necessárias para se respeitar a mulher, pois a lei enfatiza o caráter normativo destas obrigações, bem como sua face democrática, pois é preciso saber conviver com as diferenças.

Como bem salientou Saulo Ramos Furquim (2014), estes crimes não eram punidos e contavam muitas vezes com o silêncio da sociedade, apesar do seu caráter nefasto, já que é cometido por alguém que faz parte do círculo íntimo da vítima. Aquele que deveria proteger sua companheira acaba se transformando em algoz e, quando isto acontece, o poder público nada faz para punir o delito à sua altura. A lei Maria da Penha teve o mérito de trazer este tema para o debate social, trazendo a questão da punição aos praticantes desta violência operada no âmbito doméstico.

\section{A lei do feminicídio}

Se a Lei Maria da Penha pode ser considerada um marco na luta contra a violência doméstica, a lei 13.104/15, conhecida como Lei do Feminicídio, representa a grande vitória para os movimentos em defesa da dignidade da mulher, pois confere aos crimes perpetrados contra as mulheres um grau de gravidade muito maior, além de aumentar a severidade da justiça para com os agressores. Em seu preâmbulo ela deixa claro que altera o art. 121 do Decreto-Lei no 2.848, de 7 de dezembro de 1940, para prever o feminicídio como circunstância qualificadora do crime de homicídio, e o art. $1^{\circ}$ da Lei no 8.072, de 25 de julho de 1990, para incluir o feminicídio no rol dos crimes hediondos.

De fato, o código penal, criado através da lei 2.848/40, na parte que trata dos crimes contra a pessoa e contra a vida, estabelece em seu artigo 121 o homicídio simples, cuja pena é a de reclusão de 6 a 20 anos, e o homicídio qualificado, cuja pena envolve a reclusão de 12 a 30 anos.

Na redação original do código, constavam várias circunstâncias que caracterizavam o homicídio qualificado. A lei 13.104/15 incluiu entre os tipos elencados no $\S 2^{\circ}$, o inciso VII, que coloca como homicídio qualificado o feminicídio, ou seja, o crime "contra a mulher por razões da condição de sexo feminino".

Desta forma, o texto deixa claro o que pode ser considerado crime de gênero, ou em relação à condição feminina, onde aparecem a violência doméstica e familiar e o menosprezo à condição de mulher. A lei ainda acrescenta alguns agravantes que servem para aumentar ainda mais a pena, levando em consideração se o crime foi cometido durante a gestação, contra pessoa menor de 14 ou maior de 60 anos, e se o mesmo ocorrer na presença de descendente ou ascendente da vítima. 
A lei 13.104/15 também operou uma modificação importante no artigo $1^{\circ}$ da lei 8.072/90, de crimes hediondos, a qual ficou com a seguinte redação: “Art. $1^{\circ}$ São considerados hediondos os seguintes crimes, todos tipificados no Decreto-Lei no 2.848, de 7 de dezembro de 1940 - Código Penal, consumados ou tentados". Sendo assim, o feminicídio, crime praticado contra a mulher, derivado de sua condição feminina, passa a ser tratado com o rigor que merecem os crimes hediondos, conferindo ao mesmo um caráter ainda mais desqualificador como ato infame, motivado por motivo torpe.

É inegável, pois, a virada operada pela lei do feminicídio, no sentido de atacar na raiz a causa maior dos crimes contra a mulher, a saber, a violência de gênero, a tentativa sub reptícia de submeter a mulher à violência constante na certeza de que será perdoado por ter agido em função da paixão, de um arrebatamento emocional qualquer e que, por isso mesmo, serviria de pretexto para pelo menos atenuar a pena destes infratores. Neste sentido, Mariana Armond Dias Paes (2015) afirma que "fica evidente, então, que a violência sofrida pela mulher não é uma violência como outra qualquer, mas ocasionada, principalmente, pela sua condição de mulher e praticada no âmbito doméstico e familiar".

Isto se dá, segundo a autora, pela própria situação de desigualdade vivida pela mulher. Além de receber salários mais baixos em relação ao homem, ela tem que cumprir uma dupla jornada, tendo ainda a responsabilidade pelos afazeres domésticos. Em tais situações, a mulher não consegue desenvolver outras habilidades sociais e por isso mesmo acaba ficando à mercê de seus companheiros, os quais geralmente as tratam de forma a inferiorizá-las.

É esta vulnerabilidade que fomenta a discriminação e a violência desencadeada pelos parceiros e que era de certa forma justificada pela sociedade, na medida em que não legislava de forma correta e justa a este respeito. Isto não significa vitimizar a mulher, colocá-la numa posição de coitada, como é muito comum se falar hoje quando alguém levanta a bandeira dos direitos, sejam eles de qualquer ordem.

O que está em jogo aqui é a questão da proteção contra a agressão injustificada de seus companheiros, os quais, valendo-se de sua condição masculina, empreendem toda a sorte de violência sobre suas companheiras. O Estado precisa trabalhar neste caminho de resguardar as vítimas dos seus agressores, fazendo valer sobre estes todo o rigor da lei, sem margens para justificativas passionais, orientadas pela noção de superioridade do macho, másculo, desbravador, ante a fragilidade da fêmea, receptora, delicada e resignada.

Sob este aspecto importante da lei, Prado e Sanematsu (2017) dizem que:

Para além do agravo da pena, o aspecto mais importante da tipificação, segundo especialistas, é chamar atenção para o fenômeno e promover uma compreensão mais 
acurada sobre sua dimensão e características nas diferentes realidades vividas pelas mulheres no Brasil. (PRADO; SANEMATSU, 2017, p. 56).

Mais importante do que a dureza assumida pela legislação, foi sua função pedagógica, no sentido de mostrar as raízes da violência contra a mulher, colocar às claras toda a gama de relações sociais que a justificavam e que, por isso mesmo, levavam a sociedade a resignar-se com tais cenas de violência sexista.

A condição feminina passa então a ser vista com outros olhos, numa espécie de valorização suprema desta realidade, a qual não é escolhida, mas que deve ser respeitada, resguardada em toda a sua riqueza social, cultural e simbólica.

\section{ENTRE A LEI E A RE ALIDADE: A ATUAÇÃO DO ESTADO NO ENFRENTAMENTO DO FEMINICÍDIO}

Se não restam dúvidas sobre a importância da lei 13.104/15, ainda sobram dúvidas quanto à sua efetividade, visto que os homicídios contra as mulheres continuam a acontecer, muitas vezes ainda sendo justificados com o argumento da passionalidade, como se a lei não tivesse nenhuma funcionalidade. Na verdade, a grande questão é fazer com que a estrutura do Estado, totalmente voltada para a proteção e justificação da violência perpetrada pelos homens possa agora voltar-se efetivamente para a garantia de proteção da mulher.

As delegacias especializadas em violência contra a mulher representam um grande avanço neste sentido. Os núcleos de apoio, as políticas governamentais, a criação de uma secretaria executiva para as mulheres no âmbito do poder federal, representam passos importantes. É preciso dar mais celeridade e confiança às vítimas, para que elas possam recorrer às instâncias da justiça, sempre que forem vítimas da violência de seus parceiros. É sabido que aquelas que são agredidas nem sempre vão em busca da ajuda policial necessária e ao não buscarem a justiça acabam encorajando seus companheiros violentos a permanecerem com estas atitudes covardes.

Isso não quer dizer que elas fazem isto porque gostam de apanhar, ou porque são cúmplices dos seus algozes, mas muitas vezes é fruto do receio que as mesmas têm em relação à efetiva proteção que lhes será dada pelos órgãos judiciais. Isso faz com que parte desta violência fique invisível, não compondo as estatísticas oficiais das esferas municipais, estaduais e federais. É a violência invisível, que ocorre no seio familiar, mas que não encontra eco nos meios de comunicação, nos números revelados pelas secretarias que tratam do combate à violência doméstica ou mesmo as secretarias de defesa social, responsáveis pela segurança pública. 
Neste sentido, é muito importante retirar o selo de problema privado concernente às agressões sofridas pelas mulheres por parte dos seus companheiros. Estamos diante de um problema social, que precisa ser resolvido a partir da esfera pública, estatal, governamental. Esta tarefa foi inicialmente confiada às organizações em defesa da mulher, como nos fala Eva Alterman Blay (2003) em seu artigo sobre a Violência contra a mulher e políticas públicas, no qual ela diz que:

Ao longo das décadas de 1960 e 1970, feministas de classe média, militantes, políticas contra a ditadura militar e intelectuais foram se somando a sindicalistas e trabalhadoras de diferentes setores. Certamente, unidas numa visão democrática e igualitária dos direitos da mulher que suplantava diferenças partidárias e ideológicas. Formou-se um vasto movimento unido de mulheres, se considerarmos que o inimigo era comum. (BLAY, 2003, p. 45).

A formação destes movimentos foi importante, no sentido de dar visibilidade à demanda das mulheres, encorajando muitas delas a sair da penumbra e gritar por seus direitos, exigindo da sociedade um tratamento igualitário com relação aos seus direitos, que eram desrespeitados em face dos privilégios concedidos aos homens. E não só isso, como nos diz Blay (2003):

\begin{abstract}
Ao movimento feminista se aglutinou uma série de grupos que atuaram cotidianamente a favor dos direitos a melhores condições de vida, pela anistia, pela igualdade de direitos entre homens e mulheres. A formação de entidades voltadas a abrigar mulheres vítimas de violência doméstica não tardou a se formar. Por todo o Brasil grupos de ativistas, voluntárias, procuravam enfrentar todos os tipos de violência: estupros, maus tratos, incestos, perseguição a prostitutas, e infindáveis violações dos direitos humanos de mulheres e meninas. Diferentemente das décadas de 1910 e 1920, agora as denúncias destes crimes escondidos na e pela família tornaram-se públicos. Recebidos inicialmente com descrédito e sarcasmo pela mídia em geral, aos poucos foram reconhecidos. (BLAY, 2003, p. 53).
\end{abstract}

Graças a estes movimentos, os casos de violência começaram a vir à tona, a ser denunciados, o que ocasionou uma maior cobrança dos poderes públicos no sentido de seu empenho na solução destas ocorrências. Concomitante a isto foram sendo criados os conselhos de defesa da mulher, bem como as delegacias especializadas na sua proteção, fato muito relevante, pois possibilitou um tratamento diferenciado destes crimes. As delegacias comuns, quase sempre tratavam mal as mulheres, achando inclusive que as vítimas de violência eram merecedoras das mesmas. Desta forma, a mulher chegava a uma delegacia e era atendida por policiais homens, que destilavam sobre ela toda a sua visão preconceituosa e machista.

Todas estas iniciativas são fundamentais no sentido de dar maior visibilidade ao problema da violência contra a mulher, mas mostram o quanto o poder público ainda precisa se aproximar desta realidade, criando mecanismos legais e institucionais para combater a realidade presente do feminicídio em nosso país. 


\section{CONSIDERAÇÕES FINAIS}

Estamos vivendo um período em que a violência aumenta a cada dia, tornando nossas cidades lugares perigosos de se viver. Mas no caso da violência de gênero, as vítimas são atacadas não apenas nos espaços públicos, mas também no ambiente doméstico, onde em tese deveriam encontrar todo apoio e aconchego necessário ao seu desenvolvimento físico e psicológico.

Os traumas causados pelos atos de violência são muitos. Os casos registrados de crimes relacionados ao gênero mostram famílias devastadas, esfaceladas por causa de um gesto de desespero e desrespeito de alguém que se acha no direito de tirar a vida de sua parceira apenas por considerá-la sua propriedade ou por achar que deve proteger a sua honra masculina.

As mulheres ainda sentem dificuldades de fazerem a denúncia contra seus agressores, em parte por vergonha, em parte por medo de uma retaliação ainda mais forte do seu companheiro. Para muitas mulheres é difícil expor sua vida e escancarar as agressões que sofreram da parte dos seus companheiros.

Não deve ser fácil apresentar à sociedade as sequelas físicas provocadas por um ato infame de violência. É muito importante lutar para superar a cultura da violência que já se instalou na sociedade e, sobretudo, entre os casais. São estas práticas e ideias machistas que acabam criando um ambiente propício à violência masculina. É difícil imaginar que uma mulher deseje ser agredida. A violência e o assassinato de mulheres é uma chaga que ainda faz parte de nossa realidade. São fatos como estes que nos fazem refletir cada vez mais sobre a importância de se criar cada vez mais mecanismos de proteção às mulheres, pois elas são as vítimas preferenciais de um modelo machista e patriarcal de sociedade.

Este artigo mostrou as bases históricas e sociais que fundamentam o comportamento agressivo dos homens frente às mulheres, além de apresentar a evolução legislativa, que teve na Lei Maria da Penha um dos momentos principais e que redundou na importante Lei do Feminicídio.

Não há como contestar o avanço representado por estes documentos legais. A partir de então, a mulher passou a ter maior atenção e proteção da parte do Estado brasileiro. Em um Estado democrático de direito é de grande relevância que as leis contribuam para corrigir as distorções e desigualdades sociais.

No que concerne à violência contra a mulher, esta se dá por vários motivos e de inúmeras formas, desde o ato puro e simples do companheiro até o tratamento inadequado nas delegacias especializadas. Com o advento da Lei Maria da Penha, começaram a se espalhar as 
delegacias especializadas da mulher, que passaram a oferecer um tratamento mais adequado às vítimas.

Tal fato reforça a necessidade de se continuar aperfeiçoando os instrumentos legais, bem como os mecanismos capazes de lhes dar cumprimento. Neste sentido, e é sempre bom reforçar este aspecto, não basta apenas a letra da lei. É necessária sua efetivação, ou seja, que ela seja aplicada na prática e que o cidadão seja alcançado por seus benefícios.

No que concerne à Lei do Feminicídio, o endurecimento da pena e sua tipificação como crime hediondo representou um passo importante no combate às práticas cotidianas de violência contra a mulher, além de estabelecer um paralelo com o elemento sociológico presente nestas formas de agressão.

Tudo isto acaba direcionando a discussão para a condição da mulher em nossa sociedade, o que é sumamente relevante. Quando se debate o feminicídio, vem à tona o modelo de sociedade que se construiu ao longo dos séculos, que distribui privilégios aos homens e coloca a mulher em condição subalterna, devendo aceitar e assumir a culpa por ter sido agredida.

Portanto, cabe não apenas validar a lei, por meio dos instrumentos institucionais. É necessário repensar o modelo de sociedade que foi construído ao longo dos séculos e que faz com que o homem se ache no direito de agredir a mulher. Não há como dissociar a criação de um arcabouço legal e punitivo do processo educativo. Uma das formas mais eficazes, embora mais difícil e duradoura de se combater o feminicídio, é investir na educação, na formação ética. Isso requer alguns movimentos importantes.

Primeiro, é necessário estruturar a família, de modo a que os filhos sejam educados com base no respeito às diferenças de gênero, para que a mulher não seja mais vista como um ser subalterno. Por ser a base da sociedade, a entidade familiar precisa assumir seu papel de formadora, de criadora dos primeiros fundamentos de uma relação de respeito, no qual os papéis desempenhados por homens e mulheres sejam vistos à luz da ética, do respeito mútuo, fomentando a cultura da não violência.

O segundo trabalho importante se faz por meio da educação formal. A escola também precisa assumir seu protagonismo no que diz respeito à criação de um pensamento que proponha o respeito à mulher. Há que se realizar todo um trabalho de desconstrução da mulher como objeto sexual e posse do homem. Algumas disciplinas, como ética e cidadania, por exemplo, precisam ser mais valorizadas nos currículos escolares e os alunos precisam ser chamados a debater estas questões com profundidade. 
E o terceiro movimento diz respeito às ações governamentais. É de grande relevância realizar campanhas de conscientização em relação à violência contra a mulher. O Estado precisa assumir seu papel nesta jornada, fomentando o debate e chamando a atenção para a realidade. Quanto mais se debater o tema, melhor. As ações governamentais devem se dirigir ao combate firme e incansável contra as múltiplas formas de violência de gênero.

Cabe destacar também o papel das universidades, enquanto espaço plural, que acolhe e estimula a reflexão sobre os graves problemas sociais. É uma tarefa urgente e necessária, que não pode mais ser adiada. Apesar dos avanços, ainda há em nossa sociedade uma cultura de violência, que atinge principalmente as mulheres, que muitas vezes ainda são acusadas de serem as responsáveis pela violência que sofrem. Mudar este cenário é uma tarefa da sociedade e um imperativo ético.

\section{REFERÊNCIAS}

BLAY, Eva Alterman. Violência contra a mulher e políticas públicas. Estud. av. vol.17 n.49, São Paulo. Set./Dez. 2003. Disponível em: http://dx.doi.org/10.1590/S010340142003000300006 Y Acesso em: 10 nov. 2020.

BRASIL. Constituição da República Federativa do Brasil. Brasília, DF: Senado Federal: Centro Gráfico, 1988. 292 p.

Lei 11.340 de 07 de agosto de 2006. Lei Maria da Penha. Disponível em: www.planalto.gov.br. Acesso em: 16 out. 2020.

Lei 13.104 de 09 de março de 2015. Lei do Feminicídio. Disponível em: http://www.planalto.gov.br/ccivil_03/_ato2015-2018/2015/lei/113104.htm. Acesso em: 14 out. 2020.

DIAS, Maria Berenice. A Lei Maria da Penha na justiça: a efetividade da Lei 11.340/2006 de combate à violência doméstica e familiar contra a mulher. 2. ed. São Paulo: Editora Revista dos Tribunais, 2010.

FON, Lays Conceição Franco. Violência contra a mulher: notas sobre o feminicídio em Salvador/BA. UFRPE, 2014. Disponível em: http://www.ufpb.br/evento/lti/ocs/index.php/18redor/18redor/paper/view/674/702. Acesso em: 20 out. 2020 . 
FURQUIM, Saulo Ramos. A mulher no direito penal: Breves considerações à Lei $\mathrm{n}^{\mathrm{o}}$ 11.340/06. In: Âmbito Jurídico, Rio Grande, XVII, n. 130, nov. 2014. Disponível em: http://www.ambito-juridico.com.br/site/?n_link=revista_artigos_leitura\&artigo_id=15457.

Acesso em: 16 nov. 2020.

PRADO, Débora; SANEMATSU, Marisa. (Org.) Feminicídio: \#invisibilidademata. Ilustração: Lígia Wang. Fundação Rosa Luxemburg. São Paulo: Instituto Patrícia Galvão, 2017.

MINAYO, Maria Cecília de Souza (2005). Laços perigosos entre machismo e violência. Revista Ciência \& Saúde Coletiva, 10(1):23-26. Disponível em: http://www.scielo.br/pdf/csc/v10n1/a03cv10n1. Acesso em: 15 out. 2020.

PAES, Mariana Armond Dias. Inclusão do feminicídio no Código Penal é uma questão de igualdade e gênero. Conjur, 2015. Disponível em: https://www.conjur.com.br/2015.../mariana-paes-feminicidio-questao-igualdade-genero.

Acesso em: 22 nov. 2020.

SAFIOTTI, Heleieth. Gênero, patriarcado e violência. São Paulo: Editora Fundação Perseu Abramo, 2004.

SANTIAGO, Rosilene Almeida; COELHO, Maria Thereza Ávila Dantas. A violência contra a mulher: antecedentes históricos. In: Revista UNIFACS, 2007. Disponível em: www.revistas.unifacs.br/index.php/sepa/article/download/313/261. Acesso em: 19 out. 2020. 